\title{
ANALYTICKÝ POVRCHOVÝ ZBER NA LOKALITEVRÁBLE-FIDVÁR: STAV BÁDANIA A MOŽNOSTI SPRACOVANIA DÁT
}

\author{
D O M I N I K D R O Z D
}

\begin{abstract}
Systematic Field Survey at the Site of Vráble-Fidvár: State of Research and Possibilities of Data Evaluation. The early bronze age fortified settlement near Vráble-Fidvár is one of the most important archaeological sites in Europe. This paper is trying to review the fieldwalking campaign of 2007 at the site, from the perspective of methodology and state of research. Its purpose is to introduce an unconventional method of data evalution known as (spatial) sampling. The article deals with a concept of two-stage sampling which in combination with spatial interpolation aims to demonstrate an effective way of processing large archaeological datasets. Sampling design is divided into two phases. First, disproportional stratified sampling shows preliminary spatial patterns which will be completed by second phase of adpative cluster sampling. Basic information about the design, its aims and sample size are provided within.
\end{abstract}

Keywords: SW Slovakia, Early Bronze Age, fieldwalking, sampling, spatial analysis.

\section{ÚVOD}

Poloha Fidvár sa nachádza na južnom okraji mesta Vráble a predstavuje významnú a unikátnu archeologickú lokalitu nielen na Slovensku, ale aj v rámci Európy. Systematickému terénnemu výskumu opevnenej osady zo staršej doby bronzovej predchádzala povrchová prospekcia zložená z niekol'kých etáp. Okrem povrchového zberu, ktorý je predmetom tejto štúdie, boli na skúmanej ploche aplikované d’alšie metódy povrchovej prospekcie (magnetometria, geoelektrické metódy, geologické vrty), pomocou ktorých boli objavené početné objekty a ohraničená približná rozloha sídliska.

Povrchový zber bol realizovaný analytickou metódou zberu vo štvorcovej siet tzv. rastrovou metódou (obr. 1). Týmto spôsobom bola preskúmaná plocha o celkovej rozlohe 12 ha. Prínos zvolenej metódy spočíva najmä v získaní presnej priestorovej informácie jednotlivých nálezov, ktoré sú súčastou bohatého súboru dát $(2 \mathrm{t})$.

Analytický prístup k povrchovému zberu umožňuje kvantitatívne vyhodnotenie získaných dát a využitie moderných štatistických metód a priestorových analýz. Tie nielen výrazne ulahčujú prácu s materiálom, ale prispievajú aj k objektívnemu vyhodnoteniu priestorovej distribúcie dát, skúmaním vzorcov a definovaním charakteru nálezov v súvislosti so vztahmi nálezy-prostredie (primárne vplyvy) a nálezy-nálezy (sekundárne vplyvy).

Metódy analytického povrchového zberu tak vytvárajú priestor pre nové vedecké otázky, ktoré zatial' $z$ dôvodu ich absencie pri realizácii povrchových zberov neboli v slovenskej archeológii riešené.

Príspevok vychádza z dizertačnej práce, ktorá sa venuje významu rastrovej metódy pre poznanie pra- vekej a včasnohistorickej štruktúry osídlenia, ktorá je momentálne vypracovávaná na Katedre archeológie FiF UK v Bratislave. Cielom príspevku je zhodnotenie povrchového zberu z roku 2007 z viacerých hladísk (metodika, stav bádania, kvalita dostupných informácií) a predostriet pre slovenskú archeológiu netradičný prístup k vyhodnoteniu získaného materiálu prostredníctvom metód priestorovej analýzy.

\section{POVRCHOVÝ ZBER 2007}

Povrchový zber na polohe Fidvár pri Vrábloch bol realizovaný v roku 2007 Archeologickým ústavom Slovenskej Akadémie Vied v Nitre a Römische-Germanische Komission des Deutsches Archäologisches Institut vo Frankfurte nad Mohanom. Vedúcim výskumu bol za slovenskú stranu prof. PhDr. Jozef Bátora, DrSc., za nemeckú stranu dr. Knut Rassmann.

Pre potreby povrchového zberu bola zvolená analytická metóda zberu v štvorcovej sieti (rastrová metóda). Táto metóda bola použitá v rámci slovenskej archeológie vôbec prvýkrát na tak rozsiahlom nálezisku, akým bola poloha Fidvár (12 ha). Navyše ide o jeden z mála prípadov aplikácie analytického prístupu k zberom na území Slovenska. Povrchový zber na Fidvári je možné označit ako intenzívny zber (z angl. "intensive survey“), t. j. zber, ktorý sa zameriava na stopercentné preskúmanie celej alebo vybranej časti (vzorka) plochy (Orton 2000, 75). Opozitum predstavuje extenzívny zber, ktorý na základe viacerých individuálnych prieskumov tvorí závery o rozsiahlych regiónoch, pričom kvalita a presnost' $\mathrm{z}$ jednotlivých zberov majú vysokú variabilitu (Renfrew/Bahn 2012, 78). 


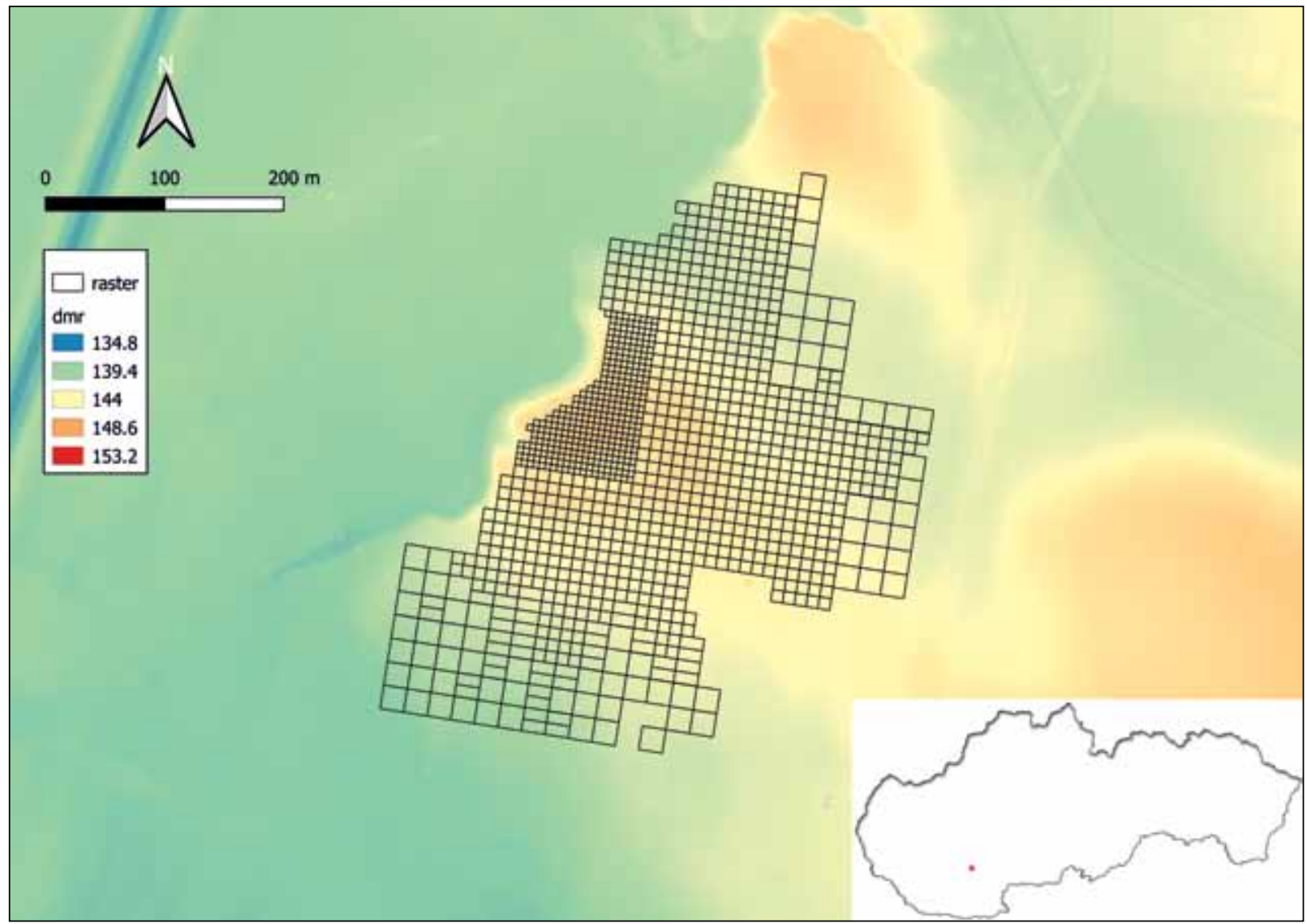

Obr. 1. Vráble-Fidvár. Štvorcová siet’ vytýčená na lokalite na podklade digitálneho modelu reliéfu (autor D. Drozd, zdroj mapy https://www.geoportal.sk/).

Hlavným cielom povrchového zberu bolo zmapovanie koncentrácie predmetov a určenie predbežnej priestorovej štruktúry sídliskového areálu (Falkenstein a i. 2008, 43-46).

Metodika zberu pozostávala z vytýčenia štvorcovej siete s vel'kostou sektorov od $5 \times 5 \mathrm{~m}$ v priestore akropoly sídliska až 20 × 20 m na periférii. Každý sektor bol označený unikátnym kódom pozostávajúcim z arabskej číslice a písmena latinskej abecedy, čo umožnilo získanie presnej priestorovej informácie o jednotlivých nálezoch. Celkovo sa počas zberu podarilo získat $2 \mathrm{t}$ materiálu, ktorý pozostával z fragmentov keramiky, mazanice, kostí a predmetov z kameňa, kovu a parohoviny (Bátora a i. 2008, 104).

Z poskytnutých dát je možné určit, že súbor keramických fragmentov, ktorý bol vyzdvihnutý počas povrchového zberu $\mathrm{v}$ roku 2007, bol tvorený celkovo 88274 nálezmi s hmotnostou 1,23 t. Známe sú aj údaje o počte a hmotnosti drobných predmetov. Keramické drobné predmety tvorilo 128 artefaktov (2493 g), kamenné 80 (8795 g), parohové 21 (968 g), kostenné $5(73 \mathrm{~g})$ a bronzové 1 exemplár (125 g; Sýkorjaková 2010).

\section{KRITIKA PRAMEŇOV}

Napriek tomu, že povrchový zber na Fidvári je možné označit za najkvalitnejšie realizovaný zber $\mathrm{v}$ rámci slovenskej archeológie, je potrebné poukázat aj na niekol'ko nedostatkov.

Hlavný problém, ktorému sa venovali aj samotní realizátori povrchového zberu (Rassmann a i. 2018), spočiva $v$ rozdielnej vel'kosti vytýčených sektorov na ploche. $Z$ dôvodu nedostatku času a presvedčenia, že nižšia presnost' získaných dát je prípustná, boli smerom k periférii sídliska sektory postupne zväčšované (Rassmann a i. 2018, 223). Aj z pohladu následného vyhodnotenia dát realizátormi zberu je už dnes zrejmé, že vhodnejším postupom by bolo udržanie rovnakej kvality zberu na celej skúmanej ploche.

Z hladiska časového obmedzenia je dôležité spomenút, že rastrová metóda nepatrí k najvhodnejším alternatívam pri prieskume rozsiahlych plôch. Poskytuje síce pomerne presnú priestorovú informáciu o artefaktoch, no časová náročnost vytýčenia štvorcovej siete je s ohladom na plochu, akou bola poloha Fidvár, príliš vysoká. Na tento fakt upozorňuje aj M. Kuna (Kuna a kol. 2004, 330). 
Nesúrodo pôsobia aj zdroje, ktoré sa venujú metodike povrchového zberu na polohe Fidvár a riešia aj otázku skutočných rozmerov sektorov. V odborných štúdiách je možné evidovat hned' niekol'ko možností, z ktorých sa však ani jedna nepreukázala ako fakticky správna. Medzi prvé zmienky patria dva články medzinárodného kolektívu autorov (Bátora a i. 2008; Falkenstein a i. 2008), ktoré zhodne uvádzajú informáciu o vel'kosti sektorov medzi 5 × $5 \mathrm{~m}$ až 20 × $20 \mathrm{~m}$. Tá bola nesprávne odcitovaná v nasledovnej bakalárskej práci, kde sa dokonca spomína uniformná vel'kost' sektorov 20 × 20 m (Sýkorjaková 2010). Práca však pravdepodobne vychádza zo získaného náčrtu štvorcovej siete, ktorý bol poskytnutý aj pre účely vyššie zmienenej dizertačnej práce. Ten kopíroval geomagnetický plán a v skutočnosti nepredstavoval reálnu terénnu situáciu. V porovnaní s originálnym náčrtom rastru je možné pozorovat' niekol'ko dôležitých rozdielov. Prevažne ide o chýbajúce alebo nadbytočné sektory (obr. 2).

Na jeho základe je možné sa mylne domnievat', že sektory majú naozaj uniformnú vel'kost' naprieč celou plochou. $V$ priebehu nasledujúcich rokov nesprávne informácie preberali d’alšie odborné články (Bátora/Tóth 2013, 33), prípadne ich neuvádzali vôbec (Bátora/Tóth/Rassmann 2015, 126).

Posledným relevantným výstupom, ktorý sa zberu na Fidvári venoval obšírnejšie, bola štúdia uverejnená v slovenskom periodiku Slovenská ar- cheológia v roku 2018 (Rassmann a i. 2018). Namiesto ujednotenia metodiky zberu však autori v článku uvádzajú odlišné údaje od starších publikácií, a navyše sú opät nepresné. $\mathrm{K}$ známym rozmerom $(5 \times 5 \mathrm{~m}, 20 \times 20 \mathrm{~m})$ sa pridáva tretí $5 \times 10 \mathrm{~m}$ (Rassmann a i. 2018, 221) a pri ilustrácii zberu aj štvrtý 10 x 10 m (Rassmann a i. 2018, obr. 5).

Reálne rozmery a rozloženie sektorov $\mathrm{v}$ priestore lokality bolo odhalené až s pomocou priestorových dát $\mathrm{v}$ podobe systému centroidov poskytnutých od dr. K. Rassmanna z RGK DAI vo Frankfurte nad Mohanom. Plocha je v skutočnosti rozdelená medzi sektory s vel'kostou $5 \times 5$ m, $10 \times 10$ m, $10 \times 20$ m a $20 \times 20 \mathrm{~m}$.

V publikovaných výstupoch taktiež chýbajú zmienky o terénnej situácii, počte účastníkov zberu, spôsobe prechádzania sektorov, prípadne čase, ktorý bol venovaný prieskumu jednotlivých sektorov. Z dostupných informácii je preto takmer nemožné odhadnút intenzitu zberu. Dá sa však predpokladat', že $z$ dôvodu časového obmedzenia a s ním súvisiacim zväčšovaním skúmaných sektorov, bola intenzita značne kolísavá a je možné očakávat postupné znižovanie kvality dát smerom k periférii sídliska.

Problematickým sa pri spracovávaní ukázal aj dostupný materiál. Pri pohlade na získané dáta je možné pri porovnaní s hodnotami uvedenými pri centroidoch sektorov vidiet' vel'ké rozdiely



Obr. 2. Vráble-Fidvár. Porovnanie náčrtu rastru s novým rastrom vytvorenom na základe GPS koordinátov. A - nový raster (autor D. Drozd); B - starý raster (podla Sýkorjaková 2010, obr. 4). 
$\mathrm{v}$ počtoch a hmotnosti súborov nálezov. Tento stav je pravdepodobne dôsledkom určitej formy skartácie. Spôsob jej realizácie je však neznámy a nie je preto možné určit jej charakter. $S$ istotou je možné vyslovit len záver, že nešlo o skartáciu atypických nálezov, ked’že tie sú v súboroch stále prítomné, spolu s inými predmetmi ako kamene, prípadne kúsky tehál.

Pri spracovávaní materiálu sa tiež ojedinele vyskytujú nezaraditelné skupiny nálezov označené nesprávnym kódom (nekompletný kód, neexistujúci sektor).

\section{VZORKOVANIE}

Analytický prístup k povrchovému zberu umožňuje kvantitatívne vyhodnotenie dát a aplikáciu metód priestorovej analýzy. Pre potreby spracovania keramických fragmentov zo zberu bola preto zvolená metóda (priestorového) vzorkovania. Rozhodnutie bolo podložené najmä analytickým charakterom povrchového zberu.

V prospech vzorkovania hovorí aj rozsiahly nálezový súbor vyzdvihnutý počas zberu. Pointa využitia vzorkovania, a štatistických metód všeobecne, spočíva v zjednodušení a sprehladnení vel'kých súborov dát.

Cielom vzorkovania je efektívnejšie spracovanie súboru keramických fragmentov s využitím náhodného výberu vzorky, zaznamenanie prítomných priestorových vzorcov a ich interpretácia v súvislosti s pravekou a včasnohistorickou sídliskovou štruktúrou. Pri analýze získanej vzorky budú využité aj predchádzajúce poznatky z distribúcie drobných predmetov (Sýkorjaková 2010) a exkavačnej činnosti.

Samotné vzorkovanie bolo rozdelené do dvoch na seba nadväzujúcich fáz. Prvá fáza bola realizovaná s využitím metódy disproporčného stratifikovaného vzorkovania. To spočíva v stratifikácii priestoru na menšie podsúbory (stratum), v ktorých prebieha náhodné vzorkovanie. Výhodou tohto prístupu je vyhnutie sa možným chybám, ktoré by mohli nastat pri jednoduchom náhodnom vzorkovaní (napr. vynechanie určitej časti mapy). Vzorka reprezentuje všetky dôležité aspekty rôznych súborov (Banning 2002, 115).

Študijný priestor lokality Vráble-Fidvár bol stratifikovaný na základe vel'kosti sektorov vo štvorcovej sieti. Týmto spôsobom vznikli štyri disproporčné strata (s rozdielnou vel'kostou populácií) označené písmenami abecedy (tabela 1).

Dôvodov pre stratifikáciu plochy na lokalite Fidvár bolo niekol'ko. Prvým bola už spomínaná rozdielna vel'kost' sektorov. Stratifikovaním plochy podla rozmerov jednotlivých sektorov bolo umožnené pracovat' so štyrmi podsúbormi, ktoré sa vyznačujú rovnakou intenzitou zberu a kvalitou získaných dát.

Rozdelenie rozsiahlej plochy sídliska na Fidvári má svoje opodstatnenie aj z hladiska zachytenia dôležitých aspektov vo variabilite skúmaných populácií. Predpoklad pred zvolením metódy vzorkovania bol, že jednotlivé definované časti sídliska (akropola, obytná čast', periféria) budú vykazovat špecifické charakteristiky a stratifikáciou priestoru bude umožnené flexibilnejšie reagovat na vznikajúce otázky.

Výsledná stratifikácia do určitej miery koreluje s rozdelením plochy určenej pre geomagnetické merania a exkavačnú fázu (obr. 3), čo napomôže jednoduchšej komparácii ich výsledkov s nadobudnutými poznatkami z povrchového zberu.

Dalším krokom bol výpočet hodnoty vel'kosti vzorky. V starších publikáciách venujúcich sa vzorkovaniu sú uvádzané hodnoty vzoriek iba odhadom, napr. 10 \% (Plog 1976, 148) alebo 20 \% (Shennan 1985, 11) bez bližšieho vysvetlenia. Moderné trendy však poukazujú na fakt, že nie je možné vyberat vzorku takpovediac „,od oka“. Ked'že neexistuje ani jednotné pravidlo, ktoré by bolo aplikovatelné pre archeologické situácie všeobecne, hodnotu vel'kosti je potrebné vypočítat' pomocou matematického vzorca aplikovaného na konkrétnu terénnu situáciu.

Rovnica sa odvíja od hodnoty intervalu spolahlivosti (najčastejšie $95 \%$ ), prípustného intervalu chyby (zvolený realizátorom vzorkovania) a štandardnej odchýlky. Problematickým sa môže javit práve odhad štandardnej odchýlky. Vo všeobecnosti existujú dve možnosti, z ktorých prvá predstavuje

Tabela 1. Vráble-Fidvár. Súhrnné informácie o vzorkovaní a stratifikácii priestoru lokality.

\begin{tabular}{|c|c|c|c|c|c|c|c|c|c|}
\hline Stratum & Populácia & $\begin{array}{c}\text { Plocha } \\
\left(\mathrm{m}^{2}\right)\end{array}$ & $\begin{array}{c}\text { Pokr_plocha } \\
\qquad\left(\mathrm{m}^{2}\right)\end{array}$ & $\begin{array}{c}\text { Váha (sila } \\
\text { strata) }\end{array}$ & Vzorka $(20 \%)$ & Vzor_n & $\begin{array}{c}\text { Vzor_n_ } \\
\text { skart }\end{array}$ & Vzor_m (g) & $\begin{array}{l}\text { Vzor_m } \\
\text { skart (g) }\end{array}$ \\
\hline A & 349 & 25 & 8725 & 0,60 & 70 & 3936 & 812 & 56847 & 15751 \\
\hline B & 698 & 100 & 69800 & 0,30 & 140 & 10432 & 1913 & 147121 & 32318 \\
\hline C & 79 & 400 & 31600 & 0,07 & 16 & 1368 & 228 & 16468 & 3444 \\
\hline D & 42 & 200 & 8400 & 0,04 & 9 & 833 & 168 & 11782 & 2610 \\
\hline Spolu & 1168 & 725 & 118525 & 1,01 & 235 & 16569 & 3121 & 232218 & 54123 \\
\hline
\end{tabular}




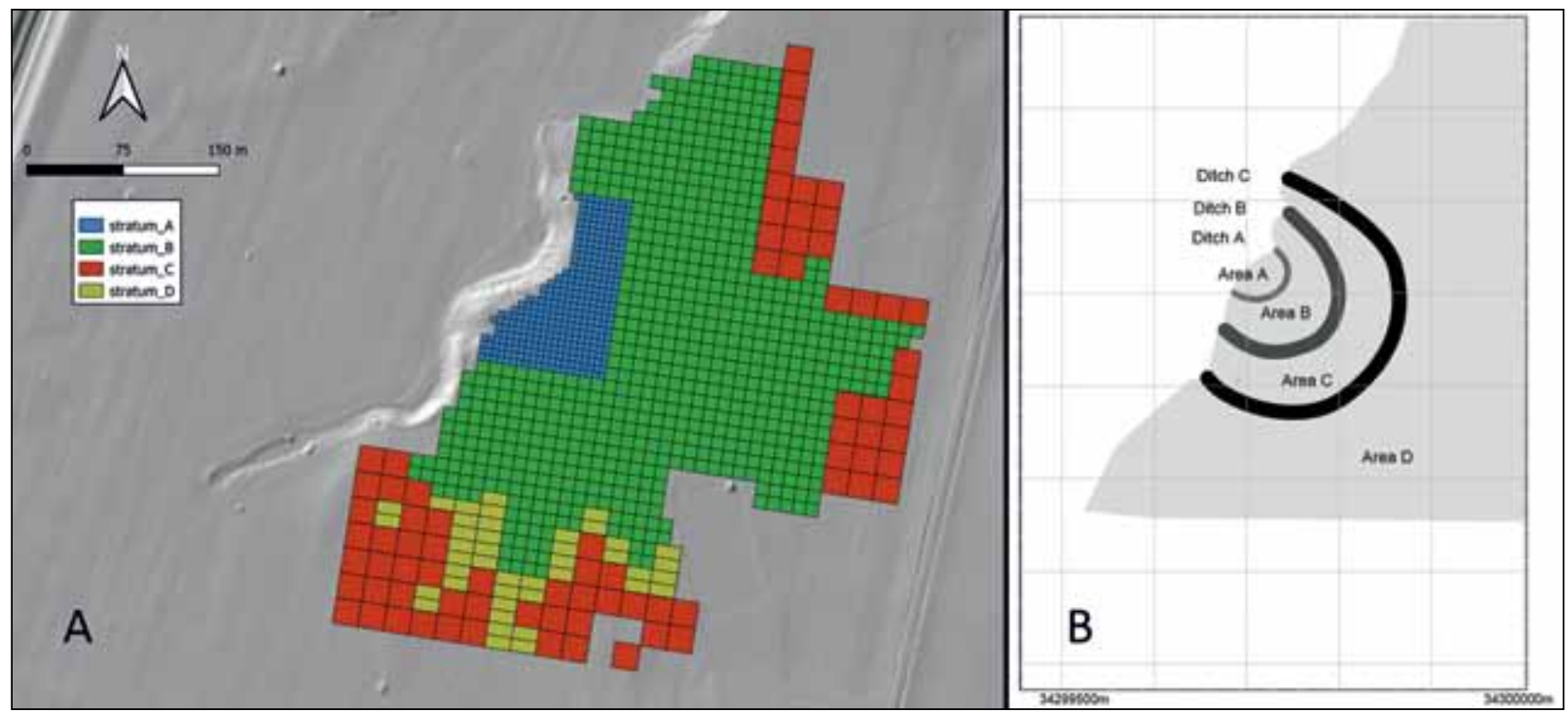

Obr. 3. Vráble-Fidvár. Porovnanie stratifikácie priestoru s rozdelením plochy z roku 2008 určeným pre geomagnetické merania a exkaváciu. A - stratifikácia (autor D. Drozd); B - rozdelenie z roku 2008 (podla Bátora a i. 2012, obr. 2).

realizáciu pilotnej vzorky a druhá získanie potrebných dát $\mathrm{z}$ iných vzoriek $\mathrm{v}$ regióne. Pre potreby výpočtu vzorky na polohe Fidvár bola zvolená prvá možnost'.

Pomocou pilotnej 3 \% vzorky bola zistená štandardná odchýlka pri počte fragmentov 53,81 a pri hmotnosti 748,51 g. Po dosadení hodnôt do vzorca bola vel'kost' vzorky po zaokrúhlení ustanovená na $20 \%$, čo predstavovalo 235 vzoriek.

Z dôvodu vytvorenia disproporčných strat musela byt๋ vzorka upravená podla ",váhy“ jednotlivých priestorov, ktorá sa odvíjala od celkového počtu sektorov v strate (tabela 1).

Prvá fáza vzorkovania sledovala dáta z kvantitatívneho a kvalitatívneho hladiska. Celkovo bolo v rámci prvej fázy vzorkovania preskúmaných 3121 keramických fragmentov s hmotnostou $57905 \mathrm{~g}$.

Kvantitatívny aspekt skúma distribúciu nálezov v priestore na základe dvoch premenných, a to celkového počtu nálezov a ich hmotnosti. Analýza priestorovej distribúcie vychádzala, z dôvodu udržania jej celistvosti, z databázy nálezov po skartácii (vychádza z nej aj kvalitatívny aspekt).

Vzorka predbežne poukazuje na vel'kú súvislú koncentráciu nálezov najmä v centrálnej časti sídliska. Zhluky nálezov boli lokalizované aj v iných častiach lokality, v ktorých však zrejme nepôjde o súvislú priestorovú distribúciu ako v prípade akropoly, ale iba o menšie ohraničené celky. Tento fakt sa potvrdil aj pri preliminárnom vyhodnotení zberu v roku 2008 (Falkenstein a i. 2008, 43-46).

Hlavným cielom kvalitatívneho aspektu bolo sledovanie vlastností keramických fragmentov a ich vývoj v priestore. Medzi vlastnosti podrobené výskumu patrilo datovanie fragmentov, zastúpenie jednotlivých častí keramických nádob a fragmentárnost' (vel'kost') predmetov.

Datovanie (obr. 4) preukázalo jednoznačnú dominanciu keramiky zo staršej doby bronzovej (najmä v centrálnom priestore; $64,8 \%$ ), v rámci ktorej sa podarilo identifikovat tri konkrétne kultúry, a to únětickú, mad’arovskú a hatvanskú. Priestorový vzorec sa v tomto prípade smerom $k$ periférii sídliska vyznačuje postupným pribúdaním keramických fragmentov zaradených do obdobia stredoveku a novoveku $(0,02 \%)$, doby rímskej $(0,006 \%)$, prípadne fragmentami neurčitel'nými $(0,31 \%)$. Minoritná čast̉ nálezov bola datovaná aj do obdobia eneolitu $(0,01 \%)$. V porovnaní s inými zbermi predstavuje datovatelnost $69 \%$ pomerne vysokú hodnotu (napr. projekt ALRNB iba 12 \%; Kuna 1998; Kuna a i. 1993). M. Kuna uvádza približnú hodnotu datovatelných pravekých keramických nálezov okolo $10 \%$ (Kuna a kol. 2004, 338).

Vysoké percento datovatel'nosti artefaktov môže byt zapríčinené už spomínanou skartáciou, po ktorej bolo podla získaných dát v prvej fáze spracovaných iba 18,8 \% nálezov (3121 z 16569 ks).

Zastúpenie častí tiel nádob v priestore nevykazuje žiadny významný vzorec a má tak skôr iba doplnkový informačný charakter o náplni jednotlivých súborov.

$\mathrm{V}$ rámci sledovania reprezentatívnosti a kvality nálezov získaných z povrchového zberu na Fidvári bola zaznamenávaná aj vel'kost' artefaktov, pomenovaná ako fragmentárnost'. Na získanie poznatkov o vel'kosti artefaktov bola zostrojená sústava na seba nadväzujúcich štvorcov s postupne sa zväčšujúcim 


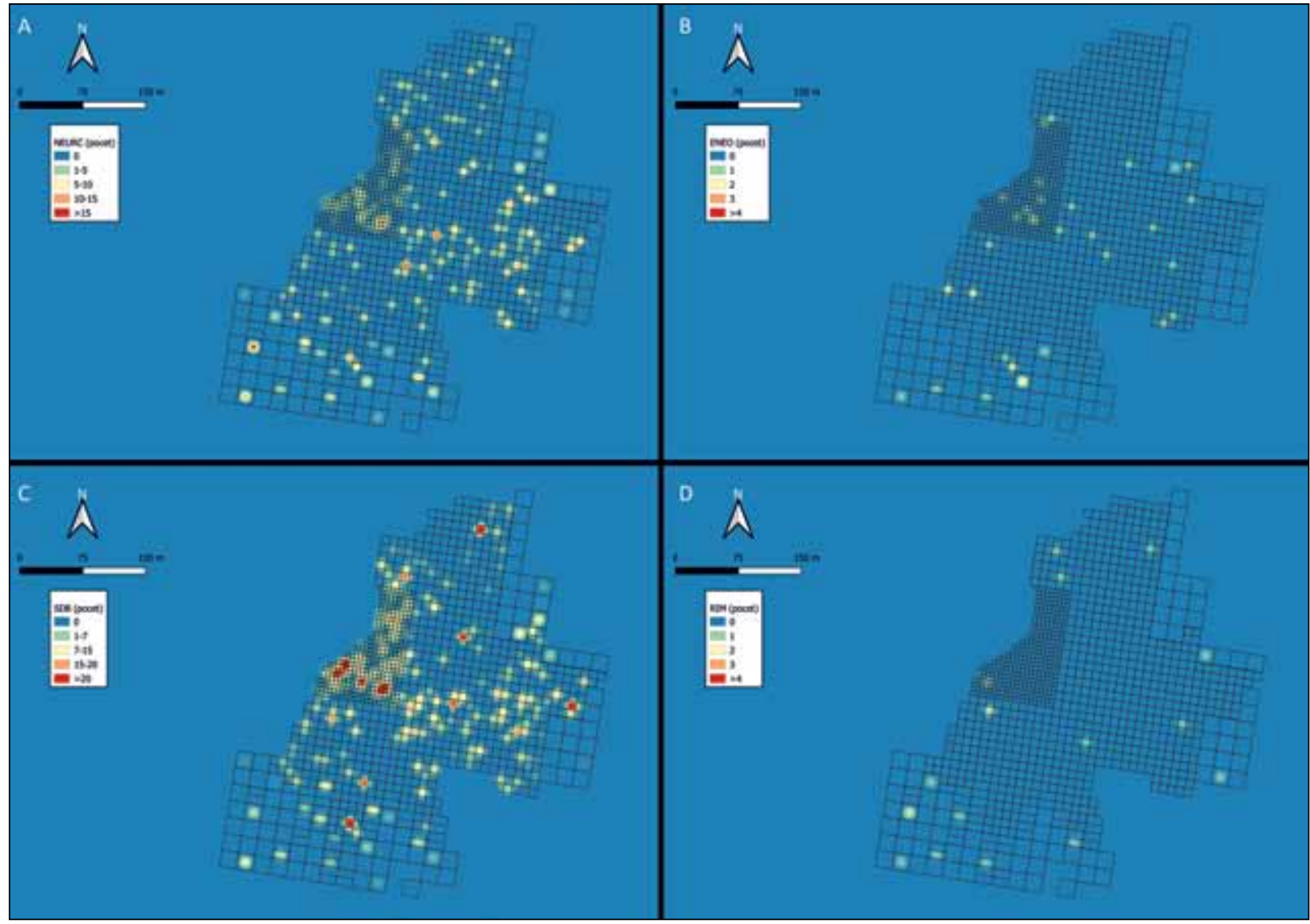

Obr. 4. Vráble-Fidvár. Priestorová distribúcia keramických fragmentov z hladiska datovania. A - neurčené; B - eneolit; C - staršia doba bronzová; D - doba rímska (autor D. Drozd).

obsahom. Týmto spôsobom vzniklo 16 vel'kostných kategórií.

Fragmentárnost’ priamo ovplyvňuje rozpoznatel'nost' typologicky dôležitých rysov keramiky, podla ktorej je možné ju datovat. V prípade lokality Fidvár je možné z výsledných hodnôt poukázat na pomerne nízku fragmentárnost' keramiky zo staršej doby bronzovej, ktorá si udržuje stabilnú hodnotu v intervale 4,1 (periféria) až 4,5 (akropola). Aj z tohto dôvodu pravdepodobne dosiahla úroveň datovatelnosti keramiky staršej doby bronzovej až takmer $65 \%$. Ako však už bolo spomenuté, vyššia kvalita môže byt výsledkom skartácie, počas ktorej mohli byt menej kvalitné fragmenty odstránené, najmä ak bol zber prednostne zameraný na dáta zo staršej doby bronzovej, čomu nasvedčujú aj publikované výstupy (Bátora a i. 2008; 2009a; 2009b; Falkenstein a i. 2008; Rassmann a i. 2018).

Pre porovnanie, nedatované fragmenty dosiahli iba hodnotu okolo 3,4 na celej ploche výskumu. Dobrá rozpoznatel'nost' sa na základe technologických prvkov (Kuna a kol. 2004, 338) preukázala na fragmentoch $\mathrm{z}$ doby rímskej a stredoveku pri nízkej hodnote len približne 4,16, respektíve 3,57. Na druhej strane pre rozoznanie eneolitickej keramiky bola potrebná vyššia kvalita črepov, približne od 4,7 až 5,9.

Okrem vel'kosti keramického fragmentu je potrebné vziat do úvahy aj jeho celkovú silu. Tú je možné vypočítat pomocou tzv. indexu fragmentarizácie, ktorý je nezávislý na druhu keramiky a vychádza zo základných údajov zaznamenávaných počas práce s keramikou (hmotnost’ a sila steny nádoby; Kuna 2012, 185).

Ďalším aspektom vyhodnotenia keramického súboru bude aj spracovanie fragmentov $\mathrm{z}$ hladiska funkčného využitia a podielu medzi tenkostennou a hrubostennou keramikou. Na základe iných výskumov (Smrž/Kuna/Kačerik 2011) existuje predpoklad postupného strácania jemnej keramiky, z čoho vyplýva možnost' hodnotenia výsledkov povrchových zberov aj na základe pomeru medzi jemnou a hrubou keramikou (Smrž/Kuna/Kačerik 2011, 192).

\section{ĎALŠÍ VÝSKUM}

V druhej fáze bola aplikovaná metóda adaptívneho zhlukového vzorkovania. Ide o metódu, ktorá 
pracuje s tzv. "pozitívnou jednotkou“ a jej „susedstvom“. Výskumu sú tak podrobené iba niektoré jednotky, ktoré splńajú dopredu definované kritériá (Orton 2000, 34). Metóda postavená na podobnom princípe ako adaptívne zhlukové vzorkovanie bola v československej literatúre rozpracovaná E. Neustupným pod názvom "sekvenčná metóda vedenia archeologického výskumu“. Tá spočíva v postupnom odkryve sond založenom na priebežnom hodnotení výsledkov výskumu, pomocou ktorých je zvolená d’alšia výskumná taktika (Neustupný 1973, 310).

Druhá fáza vzorkovania slúži na zachytenie a vymedzenie koncentrácií nálezov v priestore lokality. Pozitívna jednotka bola definovaná na základe celkového počtu keramických fragmentov v sektore. Ak počet presiahol hodnotu 20+ fragmentov na sektor, predmetná jednotka bola označená ako pozitívna. Z hladiska efektivity vzorkovania ide o najvhodnejšiu alternatívu. Pri väčšom počte fragmentov by hrozila možnost' nezachytenia dôležitých zhlukov nálezov, pri menšom by sa zas neúmerne zväčšila potrebná vzorka a samotný koncept vzorkovania by stratil svoje opodstatnenie (vzorka by mohla dosiahnut 50 až $60 \%$ ).

Susedstvo jednotky tvorili „všetky štatistické jednotky, ktoré zdielajú s pozitívnou štatistickou jednotkou spoločné strany“. Za susednú jednotku je tak považovaný každý sektor, ktorý so zvoleným sektorom zdiela jednu zo štyroch strán štvorca.

V momentálnom stave bádania boli zadefinované tri etapy druhej fázy, ktoré by mali postačovat pre vytvorenie dostatočného obrazu o lokalite a zároveň by nemali prekročit definovanú hranicu (viac ako $50 \%$ ) počtu skúmaných jednotiek. V súčasnosti je spracovávaná prvá etapa s celkovým počtom 131 jednotiek.

Druhá fáza doplní aj nízky počet vzoriek zo strat $C$ a $D$, ktoré po prvej fáze vzorkovania nemajú dostatočnú štatistickú relevantnost'. Na základe kompletnej vzorky bude možné rozlíšit a pomenovat dôležité priestorové trendy prítomné v definovaných častiach lokality.

Dalším krokom pre vytvorenie komplexného vyobrazenia distribúcie dát bude využitie interpolačných metód. Priestorová interpolácia slúži na odhad hodnôt na miestach, kde neprebehlo vzorkovanie s využitím už známych vzoriek.
Výsledkom interpolácie je súvislý rastrový model povrchu (Conolly 2020, 118). Pre výpočet hodnôt na polohe Fidvár bude testovaná najmä metóda váženej inverznej vzdialenosti a geoštatistická metóda kriging. Aplikáciou priestorových analýz bude umožnené vytvorit ucelený obraz o distribúcii dát na lokalite a znázornit priestorové vzorce (meranie anizotropie, miera priestorovej autokorelácie) iba na základe zvolených vzoriek.

\section{ZÁVER}

Príspevok sa venoval problematike povrchového zberu na polohe Fidvár pri Vrábloch. Poukázal na pozitívne, ale aj negatívne aspekty zvolenej metódy a taktiež na nesúrodé informácie o realizácii zberu. Napriek niekol'kým nedostatkom však zber na Fidvári predstavuje ojedinelý príklad analytického prístupu $\mathrm{k}$ získavaniu dát $\mathrm{z}$ povrchu terénu $\mathrm{v}$ slovenskej archeológii.

Uvedené boli predbežné výsledky aplikácie metódy vzorkovania pri spracovaní súboru keramických fragmentov. Prvá fáza poskytla informácie z kvantitatívneho aj kvalitatívneho hladiska, v ktorých sa začínajú prejavovat’ očakávané priestorové trendy a ich vývoj na ploche lokality. Taktiež umožnila vytvorenie preliminárnej súhrnnej štatistiky, ktorá môže byt̉ doplnená druhou fázou v podobe adaptívneho zhlukového vzorkovania.

Význam analytického povrchového zberu na lokalite Vráble-Fidvár spočíva v niekol'kých bodoch. Prvým je kvalitný výstup obsahujúci presnú priestorovú informáciu, ktorá tvorí základ pre využitie štatistických metód. Druhý bod spočiva v možnosti spracovania nálezov pomocou metódy vzorkovania a ich distribúcie na skúmanej ploche prostredníctvom priestorových analýz. Tie umožňujú nahliadat na získaný materiál efektívnejšou a v určitých ohladoch aj objektívnejšou optikou. V priestore dokážu odhalit a posúdit aj menej výrazné vzorce, ktoré majú tendenciu uniknút subjektívnemu pozorovaniu.

V neposlednom rade je nespochybnitelným prínosom aj možnost’ konfrontácie štatistických analýz $\mathrm{s}$ tradičnými metódami realizácie a vyhodnotenia povrchových zberov. 


\section{LITERATÚRA}

Banning 2002 - E. B. Banning: Archaeological Survey. New York 2002

Bátora/Tóth 2013 - J. Bátora/P. Tóth: Archeologický výskum na Fidvári vo Vrábloch. In: Gažová/B. Benczeová/ M. Benedik/M. Plichtová/L. Šalingová Holubcová (zost.): Teória a prax vo vedách o spoločnosti a kultúre. Zborník z konferencie doktorandov. Bratislava 2013, 31-40.

Bátora/Tóth/Rassmann 2015 - J. Bátora/P. Tóth/K. Rassmann: Centrálne sídlisko zo staršej doby bronzovej vo Vrábloch. In: J. Bátora/P. Tóth (ed.): Ked' bronz vystriedal med'. Zborník príspevkov z XXIII. medzinárodného sympózia "Staršia doba bronzová v Čechách, na Morave a na Slovensku", Levice 8. - 11. októbra 2013. Bratislava - Nitra 2015, 123-138.

Bátora a i. 2008 - J. Bátora/B. Eitel/F. Falkenstein/K. Rassmann: Fidvár bei Vráble - Eine befestigte Zentralsiedlung der Frühbronzezeit in der Slowakei. In: J. Czebreszuk/S. Kadrow/J. Müller (eds.): Defensive Structures from Central Europe to the Aegean in the $3^{\text {rd }}$ and $2^{\text {nd }}$ millenia BC. Poznań - Bonn 2008, 97-107.

Bátora a i. 2009a - J. Bátora/ B. Eitel/F. Falkenstein/K. Rassmann: Výsledky povrchovej prospekcie na lokalite Fidvár pri Vrábloch. AVANS 2007, 2009, 25-27.

Bátora a i. 2009b-J. Bátora/B. Eitel/S. Hecht/A. Koch/K. Rassmann: Fidvár bei Vráble (Kr. Nitra, Südwestslowakei). Untersuchungen auf einem äneolitisch-frühbronzezeitlichen Siedlungshügel. Germania 87, 2009, 1-21.

Conolly 2020 - J. Conolly: Spatial interpolation. In: M. Gillings/P. Hacigüzeller/G. Lock (eds.): Archaeological spatial analysis: A Methodological Guide. Abingdon 2020, 118-134.

Falkenstein a i. 2008 - F. Falkenstein/J. Bátora/B. Eitel/ K. Rassmann: Fidvár bei Vráble - Archäologische Prospektionen auf einer befestigten Zentralsiedlung der Frühbronzezeit in der Slowakei. Mitteilungen der Berliner Gesellschaft für Anthropologie, Ethnologie und Urgeschichte 29, 2008, 39-50.

Kuna 1998 - M. Kuna: Keramika, povrchový sběr a kontinuita pravěké krajiny. Archeologické rozhledy 50, 1998, 192-223.

Kuna a i. 1993 - M. Kuna/M. Zvelebil/P. J. Foster/D. Dreslerová: Field survey and landscape archaeology research

Rukopis prijatý 9. 8. 2020

Translated by Dominik Drozd design: Methodology of a regional field survey in Bohemia. Památky archeologické 84, 1993, 110-130.

Kuna a kol. 2004 - M. Kuna a kol.: Nedestruktioní archeologie. Teorie, metody a cíle. Praha 2004.

Kuna 2012 - M. Kuna: Depoziční struktura komponenty. In: M. Kuna/A. Němcová (ed.): Výpověd' sídlištního odpadu. Praha 2012, 172-205.

Neustupný 1973 - E. Neustupný: Sekvenční metoda vedení archeologických výzkumi̊. Archeologické rozhledy 25, 1973, 300-328.

Orton 2000 - C. Orton: Sampling in archaeology. Cambridge 2000.

Plog 1976 - S. Plog: Realtive Efficiencies of Sampling Techniques for Archaeological Surveys. In: K. V. Flannery (ed.): The Early Mesoamerican Village. New York 1976, 136-158.

Rassmann a i. 2018 - K. Rassmann/J. Bátora/N. Müller-Scheessel/S. Reiter/M. Ivanova/A. Behrens/K. Radloff/M. Bača: Tracing Taphonomic Processes. Multiple Layer Analysis of Ceramic Distribution from Surface Collection and Excavation at the Early Bronze Age Settlement of Vráble-Fidvár. Slovenská archeológia 66, 2018, 219-234.

Renfrew/Bahn 2012 - C. Renfrew/P. Bahn: Archaeology. Theories, Methods and Practice. London 2012.

Shennan 1985 -S. Shennan: Experiments in the Collection and Analysis of Archaeological Survey Data: the East Hampshire Survey. Sheffield 1985.

Smrž/Kuna/Káčerik 2011 - Z. Smrž/M. Kuna/A. Káčerik: Archeologie mizejíci krajiny. Terénni průzkum předpolí Dolů Nástup Tušimice. Památky archeologické 102, 2011, 159-216.

Sýkorjaková 2010 - D. Sýkorjaková: Praveké nálezy drobných predmetov z povrchových zberov a prieskumov na lokalite Vráble-Fidvár. Bakalárska práca. Katedra archeológie, Filozofická fakulta, Univerzita Komenského. Bratislava 2010. Nepublikované.

Mgr. Dominik Drozd

Archeologický ústav SAV

Akademická 2

SK - 94921 Nitra

drozd10@uniba.sk 


\title{
Systematic Field Survey at the Site of Vráble-Fidvár: State of Research and Possibilities of Data Evaluation
}

\author{
Dom in ik D rozd
}

SUMMARY

The site of Vráble-Fidvár is one of the most important sites in Slovakia and Europe. Large-scale excavations were preceded by a surface survey in 2007, which consisted of geophysical survey and field-walking. Fieldwalking was based on a grid method and yielded a fairly rich collection of pottery, animal bones, stone and clay artefacts.

The use of an analytical approach during the field survey allowed to employ the methods of spatial statistics. Whole space was divided into four strata, based on the inconsistent area of individual quadrats. For the evaluation of the collected finds a two-phased sampling procedure is considered. First phase, by using the technique of proportional stratified sampling, yielded preliminary

Fig. 1. Vráble-Fidvár. Grid over the site (author D. Drozd, source https://www.geoportal.sk/).

Fig. 2. Vráble-Fidvár. Comparision of an older sketch of grid with a new one based on the GPS coordinates. A - new grid (author D. Drozd); B - old grid (after Sýkorjaková 2010, fig. 4).

Fig. 3. Vráble-Fidvár. Comparision of spatial stratification with an area divided for the purpose of geomagnetic prospec- results in both quantitative and qualitative aspect. Even though, the quantitative one shows some larger clusters in certain areas of the site, it can't be considered useful due to lack of samples in smaller strata (C and D). On the other hand, the qualitative variables are demonstrating a visible pattern of decline of quality and size towards the periphery of the site.

A second phase of adaptive cluster sampling will be conducted in selected areas to capture the spatial trends that are present at the site. Samples will be then interpolated using various methods (inverse distance weighting, kriging) and a continuous surface model will be created using just the discrete sample points.

tion and excavation. A - stratification (author D. Drozd); B - divided area 2008 (after Bátora a i. 2012, fig. 2).

Fig. 4. Vráble-Fidvár. Spatial distribution of potsherds (dating). A - not assigned; B - Eneolithic; C - Early Bronze Age; D - Roman period (author D. Drozd).

Table 1. Vráble-Fidvár. Information about sampling and spatial stratification of the site. 
